\title{
Taşınmaz değer haritalarının coğrafi bilgi sistemleri ile üretilmesi: Çanakkale örneği
}

\author{
Müge Özgüven ${ }^{1}$, Ramazan Cüneyt Erenoğlu+® \\ ${ }^{1}$ Çanakkale Onsekiz Mart Üniversitesi, Terzioğlu Kampüsü, Mühendislik Fakültesi, Harita Mühendisliği Bölümü, Çanakkale, Türkiye.
}

\begin{abstract}
Öz: Değer haritaları, taşınmaz değerlemede etkin olarak kullanılmaktadır. Çanakkale ili, Merkez ilçesi, Esenler Mahallesi sınırları dahilinde bulunan yapısız, arsa vasıflı 87 adet parsel tespit edilmiștir. Öncelikli olarak arsa değerine etki eden 15 adet faktör belirlenmiştir. Belirlenen faktörleri kapsayan, analitik hiyerarşi sürecine (AHS) göre hazırlanan anket çalışmasina, 15 gayrimenkul değerleme uzmanı katılmıştır. Tutarlılık oranı, sınır değer içerisinde bulunan 6 adet anket değerlendirmeye alınmıştır. AHS'ye göre gerçekleştirilen değerlendirme sonucunda faktörlerin ă̆ırlıkları belirlenmiştir. Anket çalışması sonucunda belirlenen faktörlerin ağırlıkları; \%16.7 toplam inşaat alanı, \%15.0 kamu hizmetlerinden yararlanma, \%13.4 imar durumunda ada kullanımı, \%9.0 depremsellik, \%8.9 zemin durumu, $\% 8.5$ eğim, \%5.9 parselin ada içindeki konumu, \%4.7 parsel şekli, \%4.2 bakl, \%3.3 manzara, \%2.6 ana caddeye olan uzaklik, \%2.5 merkeze olan uzaklık, \%1.9 ĕgitim alanına uzaklık, \%1.7 yeşil alana uzaklık ve \%1.6 sağlık alanına olan uzaklık şeklinde belirlenmiştir. Çalışma alanını kapsayan her bir faktöre ait haritalar üretilmiştir. Belirlenen ağırlık oranları göz önünde bulundurularak, çalışma alanında yer alan yapısız parsellere ait değer haritası oluşturulmuştur.
\end{abstract}

Anahtar Sözcükler: Taşınmaz değerleme, Değer haritası, Coğrafi bilgi sistemleri, Analitik hiyerarşi süreci, Nominal değerleme, Yapısız parsel

\section{Production of real estate value maps with geographical information systems: The case of Çanakkale}

Abstract: Value maps are used as active in real estate valuation. 87 structureless parcels of land qualified within the borders of Esenler Quarter of the Central district of Çanakkale province were identified. Firstly, fifteen factors affecting the land value were determined. Fifteen real estate appraisers participated in the survey which was prepared according to the analytical hierarchy process (AHP). Six questionnaires, whose consistency ratios are in the limit, were evaluated. As a result of the evaluation performed according to AHP, weights of factors were determined. The weights of the factors as a result of the survey; $16.7 \%$ total construction area, $15.0 \%$ utilization of public services, $13.4 \%$ island use in development, $9.0 \%$ earthquake condition, $8.9 \%$ soil condition, $8.5 \%$ slope, $5.9 \%$ parcel position within the island, $\% 4.7$ parcel shape, $4.2 \%$ aspect, $3.3 \%$ view, $2.6 \%$ distance to main street, $2.5 \%$ distance to center, $1.9 \%$ distance to educational area, $1.7 \%$ distance to greenery $1.6 \%$ distance to the health area. Maps of each factor covering the study area were produced. The value map of the unstructured parcels in the study area was created.

Keywords: Real estate valuation, Value map, Geographic information systems, Analytic hierarchy process, Nominal valuation, Unstructured parcels 


\section{Giriş}

Taşınmaz değerleme ile vergilendirme ve kamulaştırma işlemlerinde rayiç bedel tespitinin yapılması, bankacılıkta ipotek ve teminat değerlerinin belirlenmesi, şirketlerin duran varlıklarının tespit edilmesi, piyasada el değiştirme bedelinin belirlenmesi, muhammen bedelinin takdir edilmesi, mülkiyet haklarının ayrıntılı araştırılması ve raporlanması, taşınmazların intikali ile değerinin belirlenmesi gibi birçok işlem gerçekleştirilebilmektedir (Çakır, 2013). Son 15 yıllık süreçte ülkemizde taşınmaz değerleme alanı gelişim göstermiştir. Taşınmaz değerleme uygulama esaslarının, değerleme yöntemlerinin ve taşınmazların değerine etki eden faktörlerin standartlaşması ile ilgili çalışmalar devam etmektedir. Taşınmaz değerlemenin giderek önem arz ettiği öngörüsü ile taşınmaz değerleme sisteminin oluşturulması gerekmektedir. Oluşturulan sistem ile birlikte daha hızlı, daha güvenilir ve daha kontrollü değer takdir işlemleri gerçekleştirilebilecektir. Coğrafi bilgi sistemleri (CBS), konumsal ve öznitelik verilerinin toplandığı, saklandığı ve görselleştirildiği, aynı zamanda sorgulama ve analiz işlemlerinin de yapılabildiği bir sistemdir (Yomralıoğlu, 2015). Taşınmaz değerleme ile CBS'nin ortak kullanılması ile değer haritaları oluşturulabilmektedir. Değer haritaları ile konumsal analizler, taşınmazlar ile ilgili sorgulamalar, uygun yer analizi, bölgelere ait birim fiyatların tespiti, yatırım yapılacak bölgelerin seçilmesi gibi işlemler kolayca gerçekleştirilebilmektedir. Geleneksel değerleme yöntemlerinin yetersiz kaldığı bölgelerde toplu veri setleri ile toplu değerleme işlemleri yapılmak istendiğinde, taşınmazların daha hızlı ve daha güvenilir şekilde değerlemesinin yapılması değer haritaları ile gerçekleştirilebilmektedir. CBS ile birlikte taşınmaz değerlemeye ait konuma dayalı güncellenebilen, nitelikli ve doğru veri tabanı oluşturulabilmektedir.

Değer haritalarını konu alan birçok çalışma gerçekleştirilmiştir. Nişancı (2005), piksel tabanlı nominal değer haritası oluşturmuştur. Nominal tabanlı taşınmaz değerleme model tasarımı ile kentsel değer haritaları ile ilgili çalışma yapmıştır. Bahar (2007), taşınmaz değerlemesinde CBS'nin kullanım olanaklarını araştırmıştır. Taşınmaz değerleme ile ilgili veri tabanı sistemlerinin oluşturulması ve çoklu karar verme yöntemleri ile değerleme yapılabilmesi konuları üzerine çalışma gerçekleştirmiştir. Özfidan (2008), Mapinfo Pro 7.0 yazılımı ile Yenişehir bölgesinde taşınmaz değerlemesi tasarımı ve uygulaması gerçekleştirmiştir. Deveci ve Yılmaz (2009), Afyon ili, Merkez ilçesinde nominal değerleme yöntemi kullanarak CBS destekli taşınmaz mal değerlemesi gerçekleştirmiştir. Torun (2009), taşınmazın değerine etki eden sosyal ve çevresel faktörleri çoklu karar verme analizi ile incelemiştir. Ankara ili, Yenimahalle ilçesinde CBS tabanlı taşınmaz değer haritası üretmiştir. Timur (2009), İstanbul ili, Şişli ilçesinde CBS ile raster tabanlı değer haritası üretmiştir. Değerleme yöntemi olarak nominal değerleme yöntemi kullanmıştır. Ünlü (2010), Eskişehir ili, Tepebaşı ilçesinde 26 mahalle için karşılaştırmalı değer haritası üretmiştir.

Yılmaz (2010), AHS ile değerleme modeli geliştirmiş ve konut amaçlı kullanılan taşınmazlara uygulamıştır. Döner (2010), taşınmaz değerleme alanında mobil tabanlı CBS uygulaması üzerine çalışma gerçekleştirmiştir. Çakır (2013), arsa vasıflı taşınmazların değerine etki eden faktörlerin belirlenmesi için anket çalışması yapmıştır. Faktörlerin ağırlıklarının belirlenmesini ise varyans analizi ile gerçekleştirmiştir. Derinpınar (2014), bulanık mantık ve nominal değerleme işlemleri ile belirli bir bölgede yer alan arsaların değer haritasını üretmiştir. Yener (2017), değer haritası kavramı, değer haritası yardımıyla değer tespiti, değer haritalarının oluşturulması, harita üzerinde yer alan herhangi bir taşınmazın değerinin belirlenmesi konuları üzerine çalışma gerçekleştirmiştir. Mete (2019), CBS ile İstanbul ili nominal taşınmaz değer haritasının oluşturulması çalışmasını gerçekleştirmiştir.

Yacim ve Boshoff (2008), yapay sinir ağları algoritmalarını küme değerlemesinde kullanarak değerlemede kullanılan yöntemleri genişletmişlerdir. Stylianidis, Roustanis ve Karanikolas (2009), mekânsal bilgilerin toplanması, betimlenmesi, taşınmaz değerleme ve arazi yönetimini kapsayan coğrafi bilgi tasarımı olan 'GEOVAL' sistemi üzerine çalışma 
yapmışlardır. Zeng ve Zhou (2001), kural tabanlı bir sistemi, bulanık küme teorisi ve CBS’yi bir araya getirerek prototip taşınmaz değerleme sistemi geliştirmişlerdir. Taşınmaz sektöründe alıcılar ile satıcılar arasında mülk yönetiminde kullanılabilecek asistan uygulama REGIS sistemini oluşturmuşlardır.

Literatür araştırması sonucunda gerçekleştirilen çalışmada AHS kullanılarak Çanakkale ili, Merkez ilçesi, Esenler Mahallesi'nde yer alan yapısız parsellere ait değer haritasının, CBS ile üretilmesi amaçlanmaktadır. Çalışmada, arsaların değerine etki eden faktörlerin ve önem derecelerinin belirlenmesi, güncellenebilen, bölgeyle ilgili analizleri kolaylaştıracak, taşınmazın değeri ve rayiç bedel tespitinde hata payını azaltacak veri tabanının oluşturulması, gelişim gösteren, piyasada talep gören, ticari fonksiyonlu gelişen, yatırım amaçlı kullanılabilecek taşınmazların tespit edilmesi hedeflenmiştir.

\section{Yöntem}

Çalışma kapsamında Çanakkale ili, Merkez ilçesi, Esenler Mahallesi'nde yer alan yapısız parsellerin değer haritasının oluşturulması amaçlanmıştır. Taşınmaz değer haritalarının oluşturulmasında temel aşama taşınmazların değerine etki eden faktörlerin ve bu faktörlerin ağırlıklarının belirlenmesidir. Çalışmanın işlem adımları Şekil 1'de gösterilmektedir.

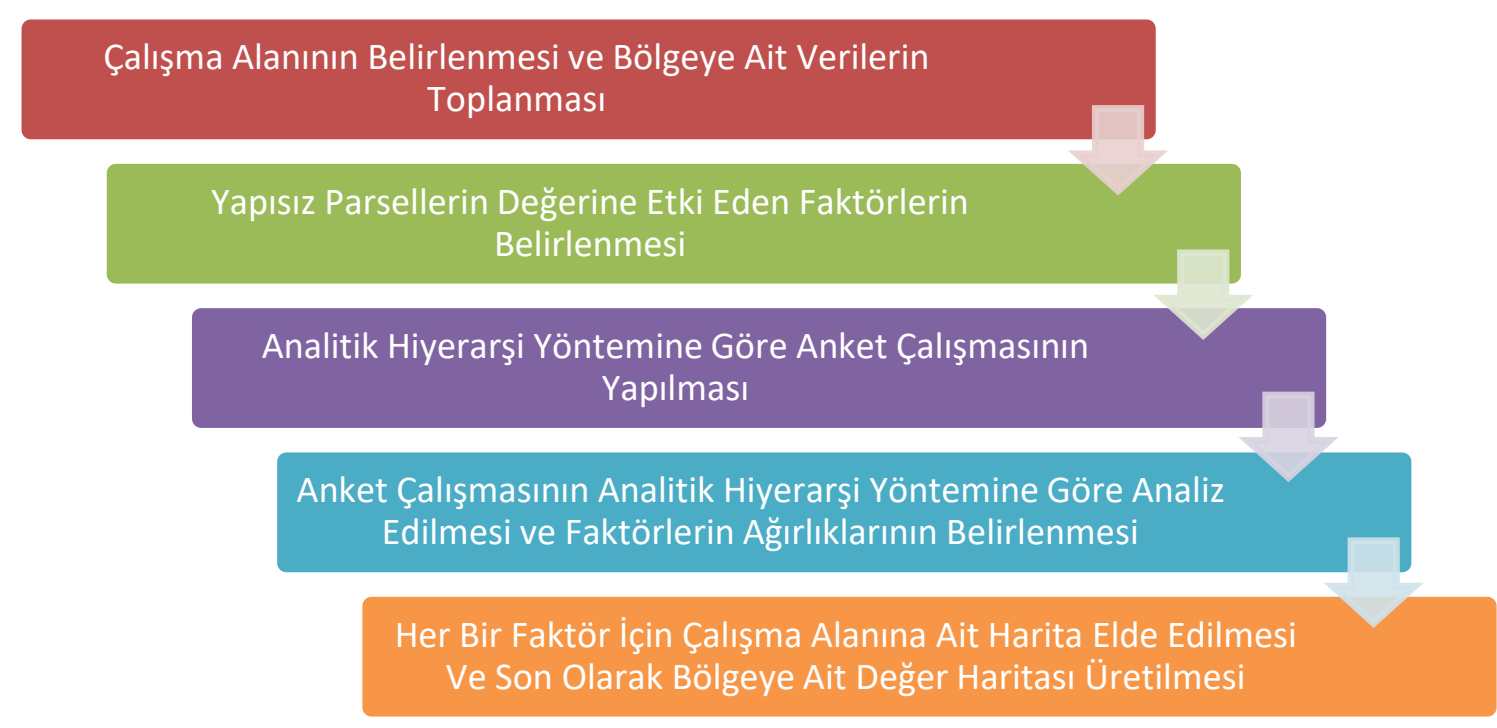

Şekil 1: Çalışmanın işlem adımları

\subsection{Arsa Vasıflı Taşınmazların Değerine Etki Eden Faktörler}

Bulunduğu bölgede hazırlanan imar planı kapsamında düzenlenen, asgari düzeyde alt yapısı sağlanmış arazi parçası olarak tanımlanan arsaların değeri; sosyo-ekonomik, fiziksel ve yasal durumlara göre farklılık göstermektedir. Taşınmazların karşılaştırılmasında değere etki eden faktörlerin ağırlıkları göz önünde bulundurularak gerekli şerefiye düzeltmeleri ile değer takdiri işlemi gerçekleştirilmektedir. Taşınmazlar için kesin değer tespiti söz konusu değildir. Taşınmazın değerini etkileyen faktörler, bölgeye ve kişilere göre farklılık gösterebilmektedir. Faktörler ayrı ayrı değerlendirilerek birim alan üzerinden taşınmazın değer tespiti gerçekleştirilebilir (Yomralığlu, Nişancı \& Uzun, 2007).

Arsa vasıflı taşınmazların değerine etki eden faktörler, bölgenin talepleri ve özellikleri göz önünde bulundurularak; kamu hizmetlerinden yararlanma, parsel şekli, depremsellik, zemin durumu, toplam inşaat alanı, parselin ada içindeki konumu, manzara, bakı, eğim, imar durumunda ada kullanımı, merkeze olan uzaklık, ana caddeye olan uzaklık, eğitim alanına uzaklık, yeşil alana uzaklık ve sağlık alanına uzaklık başlıkları altında toplanabilir. Bu başlıklara ait kısa bilgiler aşağıda sırasıyla verilmiştir. 
Kamu Hizmetlerinden Yararlanma: Parselin, bulunduğu bölgede bulunan mevcut kamu hizmetlerinden yararlanma durumunu kapsamaktadır. Bölgede bulunan hizmetler elektrik, yol, kanalizasyon, doğalgaz ve su olarak sıralanmaktadır.

Parsel Şekli: Parselde bulunan kırık köşe sayıları parselin şeklini belirlemektedir. Parselin şekli, inşaat ve inşaat maliyetlerine yansıdığından arsa değerini etkileyen önemli faktörlerdendir (Yomralıŏglu, 1997).

Depremsellik: Parsellere ait deprem potansiyeli olarak tanımlanmaktadır. Afet ve Acil Durum Yönetimi Başkanlığı tarafından oluşturulan Türkiye Deprem Tehlike Haritası ve İnteraktif Web Uygulaması'na göre en büyük yer ivmesi dikkate alınarak parsellerin depremselliği derecelendirilebilmektedir. Parselin yer ivmesi derecesi ile arsa değeri ters orantılıdır.

Zemin Durumu: Parsellerin zemin sınıfı, heyelan ve sıvılaşma riski gibi özellikleri zemin durumu başlığı altında incelenmektedir. Parsellerin zemin durumu, depremsellik ile birlikte arsa değerini etkileyen en önemli faktörlerdendir. Zemin durumu hem inşaat maliyetini hem de parselin tercih edilebilirliğini etkilemektedir.

Toplam İnşaat Alanı: Parselin imar durumu göz önünde bulundurularak parselin net alanı ile imar durumunda belirtilen kat alanı kat sayısı (emsal) ile çarpılmasıyla toplam inşaat alanı hesaplanmaktadır. Parsel üzerine inşa edilecek yapının toplam alanı, inşaat aşamasında göz önünde bulundurulan en önemli özellik olması sebebiyle toplam inşaat alanı parselin değerini etkilemektedir.

Parselin Ada İçindeki Konumu: Ada içerisinde yer alan parselin ara veya köşe parsel olması parselin tercih edilebilirliğini etkilemektedir. Köşe parsel, ara parsele göre daha tercih edilebilir durumdadır.

Manzara: Parsellerin orman veya deniz manzarasının bulunması arsa değerine etki eden faktörlerdendir.

Bakı: Bakı, parselin değerine etki eden fiziki faktörlerden biridir. Bakı, parselin konumu sonucunda Güneş 1şınlarını alış yönü olarak açıklanmaktadır. Kuzey yarım kürede, güney cephe diğer cephelere kıyasla daha avantajlı durumdadır.

Eğim: Parsellerin topoğrafik yapısı, parsel üzerine yapılacak inşaatın maliyetini ve toplam inşaat alanını etkilemektedir. Eğimi az olan parsel daha tercih edilebilir durumdadır.

İmar Durumunda Ada Kullanımı: Parselin bölge için hazırlanmış imar planında yer aldığı lejant, parselin değeri açısından önem arz etmektedir. Konut, ticaret, turizm ve sanayi alanları, belediye hizmet alanı, gelişme konut alanları, tarım alanı tercih edilebilirlik açısından farklılık göstermektedir.

Merkeze, Ana Caddeye, Eğitim, Sağlık ve Yeşil Alanlarına olan Uzaklık: Bu faktörler parselin bulunduğu bölgeye göre farklılık göstermektedir. Parselin bölgede yer alan ana caddelere, eğitim, sağlık ve yeşil alanlarına olan mesafesi ve bölge için tanımlanan merkeze olan mesafesi arsanın değerine etki eden faktörlerdendir. Parselin belirtilen alanlara mesafesinin az olması avantajlı kabul edilmektedir. Arsanın değeri ile belirtilen alanlara uzaklığı ters orantılıdır (Yomralığlu, 1997).

\subsection{Analitik Hiyerarşi Süreci}

Bir problemin çözümü için karar sürecinde, problemin çözümüne karar verilmesi ile ilgili birçok ölçüt bulunduğunda belirtilen durumlar Çok Ölçütlü Karar Verme (ÇÖKV) problemi olarak incelenebilir (Esogbue, Theologidu \& Guo, 1992; Timor, 2011; Tsai, Leu, Liu, Lin \& Shaw, 2010). ÇÖKV yöntemleri, karar verilmesi gereken problemle ilgili tüm faktörleri değerlendiren, karar aşamasında süreçle ilgili birden çok kişiyi kapsayan analitik yöntemlerdir (Görener, 2014). ÇÖKV, niteliğine ve amacına göre Çok Amaçlı Karar Verme (ÇAKV) ve Çok Nitelikli Karar Verme (ÇNKV) olarak iki gruba 
ayrılmıştır. ÇNKV'de problemle ilgili ölçütlerin niteliklerine göre sıralaması yapılmaktadır. ÇNKV yöntem olarak başlıca yedi tekniği kullanmaktadır. Bu teknikler AHS, PROMETHEE, ELECTRE, MAUT, TOPSİS, UTADİS ve analitik ağ süreci (Analytic Network Process, ANP)'dir (Ciritci \& Türk, 2019; Lai, 1995; Leung, Muraoka, Nakamoto \& Pooley, 1998; Saaty, 1980).

Çalışmada arsa vasıflı taşınmazların değerine etki eden faktörlerin ağırlıklarının belirlenmesinde AHS kullanılmıştır. AHS'de, ölçütler arasında önem derecelerine göre bir hiyerarşi yapısı oluşturulmaktadır. AHS'de çözüm aşamaları bulunmaktadır. Bu aşamalar sırasıyla; hedeflerin belirlenmesi ve listelenmesi, hedeflere ulaşabilmek için gerekli ölçütlerin belirlenmesi ve listelenmesi, ölçütler göz önünde bulundurularak problemle ilgili karar alternatiflerinin oluşturulması ve son olarak hiyerarşik modelin oluşturulmasıdır (Ciritci \& Türk, 2019; Lai, 1995; Leung vd., 1998; Timor, 2011). AHS'de hiyerarşi modeli oluşturulduktan sonra gerçekleştirilecek üç aşamalı işlem adımı aşağıdaki gibidir:

- Karşılaştırma Matrislerinin Oluşturulması: Belirlenen faktörlerin listelenmesi ve sonrasında ikili şekilde her bir faktörün önem derecelerinin puanlanması gerekmektedir. Karşılaştırma matrisi oluşturulduktan sonra normalize edilmiş matrisin hesaplanması gerekmektedir (Alonso \& Lamata, 2006).

- Öncelik Matrisinin Oluşturulması: Elde edilen normalize edilmiş matris, ortalama alınarak öncelik vektörü oluşturulur. Öncelik vektörü ile karşılaştırma matrisi sonucunda tüm öncelikler matrisi elde edilir (Timor, 2011).

- Uyum Oranının Hesaplanması: Tüm öncelikler matrisinin, öncelikler vektörüne bölündükten sonra elde edilen değerlerinin ortalaması alınır. Elde edilen ortalama ile uyum indeksi (Consistency Index, CI) aşağıdaki formül yardımıla hesaplanmaktadır (Alonso \& Lamata, 2006):

$C I=\left(\lambda_{\text {maks }}-n\right) /(n-1)$

CI hesaplandıktan sonra rastgele değer indeksi seçilir. Sonrasında CI'nın, rastgele değer indeksine oranıyla uyum oranı hesaplanır. Burada geçen $\lambda_{\text {maks }}$ büyüklüğ̈̈ özdeğeri, $n$ büyüklüğü ise karşılaştırılan alternatiflerin sayısı olup iyi bir tutarlılık ölçütüdür (Alonso \& Lamata, 2006). Uyum oranının 0.10'dan yüksek ya da düşük çıkması durumuna göre karşılaştırmanın tutarlı olup olmadığına ulaşılır (Akgün vd., 2014). Uyum oranının, sınır değerden düşük çıkması durumunda yapılan karşılaştırmalar kabul edilebilir (Timor, 2011).

AHS'nin birçok avantajı bulunmaktadır. Belirlenen ölçütler, ikili karşılaştırmalar yapılarak değerlendirildikleri için çok sayıda ölçütün matrise eklenmesinde herhangi bir sıkıntı bulunmamaktadır. Yöntem çok fazla sayıda ölçüt ve alternatifin olduğu problemlerde esnek modelleme avantajı ile çözüm üretmektedir (Timor, 2011; Turan, 2014). Buna karşın karar vericilerin yönlendirdiği bir yöntem olduğu için sonuçları test etmenin analitik bir yolunun bulunmaması, yeni bir ölçütün probleme dahil edilmesiyle önem sırasının değişmesi ve ölçütlerin göreceli olması sebebiyle mutlak ölçeklerin verilememesi AHS'nin dezavantajları arasındadır (Alonso \& Lamata, 2006; Timor, 2011).

\subsection{Analitik Hiyerarşi Sürecinde Ağırıklandırma: Anket Çalışması}

Taşınmaz değer haritalarının oluşturulmasında temel aşama taşınmazların değerine etki eden faktörlerin ve bu faktörlerin ağırlıklarının belirlenmesidir. Çalışma kapsamında arsa vasıflı taşınmazların değer haritasının oluşturulması amaçlanmışıı. Literatür araştırması göz önünde bulundurularak arsa vasıflı taşınmazların değerine etki eden faktörler belirlenmiştir (Ciritci \& Türk, 2019; Çakır, 2013). Bu doğrultuda belirlenen 15 faktör ile AHS'ye göre anket formu oluşturulmuştur. İnternet ortamında oluşturulan anket formu 15 gayrimenkul değerleme uzmanı tarafından cevaplanmıştır. 
Katılımcıların eğitim durumunu, mesleki yetkinliğini ve mesleki tecrübe süresini öğrenmek amacıyla çoktan seçmeli sorular hazırlanmıştır. Katılımcılardan 9 kişi lisans, 6 kişi ise yüksek lisans mezunudur. Katılımcılardan 7 kişi, çözüm ortaklığı şeklinde çalışan gayrimenkul değerleme uzmanı, 3 kişi sorumlu gayrimenkul değerleme uzmanı, 2 kişi denetmen, 1 kişi ise kadrolu olarak çalışan gayrimenkul değerleme uzmanıdır. 2 kişi ise diğer seçeneğini işaretlemiştir. Katılımcıların mesleki tecrübe süresi, 0-3 yı1, 3-5 yıl, 5-10 yıl ve 10+ yıl olmak üzere 4 seçenek şeklinde sinıflandırılmıştır. Katılımcılardan 7 kişi 5-10 yıl, 4 kişi 3-5 yıl, 3 kişi 0-3 yıl, 1 kişi ise 10+ yıl seçeneğini işaretlemiştir. AHS’ye göre hazırlanan anketlerin değerlendirilmesi elektronik tablo yazılımı (Excel) ile gerçekleştirilmiştir. Excel ortamında düzenlenen hesaplamada anketlerin her birinin tutarlı olup olmadığının tespit edilmesi amaçlanmıştır. Anketlerde verilen cevaplar göz önünde bulundurularak 15 faktörün karşılaştırma matrisleri oluşturulmuştur (Tablo 1). Karşılaştırma matrislerinin uyum oranları hesaplanmıştır. AHS'de tutarlılık oranı tablosuna göre faktör sayısı göz önünde bulundurularak tutarlı1ık oranı 1.59 olarak hesaplanmıştır. Uyum oranları ile tutarlılık oranı karşılaştırılarak anketlerin tutarlı olup olmadığı tespit edilmiştir.

Tablo 1: Karşılaştırma matrisi

\begin{tabular}{|c|c|c|c|c|c|c|c|c|c|c|c|c|c|c|c|}
\hline & 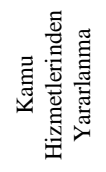 & 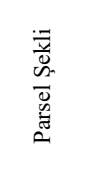 & 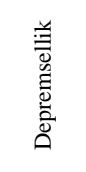 & 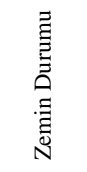 & 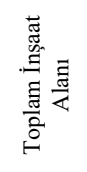 & 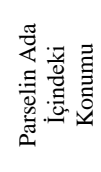 & 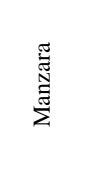 & $\frac{\bar{u}}{\tilde{m}}$ & 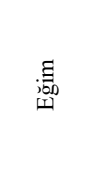 & 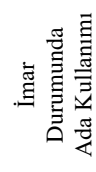 & 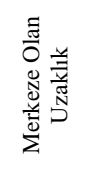 & 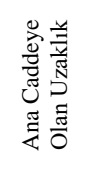 & 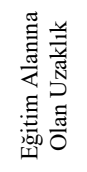 & 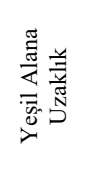 & 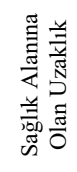 \\
\hline $\begin{array}{c}\text { Kamu } \\
\text { Hizmetlerinden } \\
\text { Yararlanma }\end{array}$ & 1.0000 & 3.4878 & 3.8730 & 2.6386 & 0.7937 & 3.9416 & 4.2976 & 4.0442 & 2.6960 & 1.8171 & 4.1074 & 4.3946 & 5.0265 & 5.0265 & 5.0265 \\
\hline Parsel Şekli & 0.2867 & 1.0000 & 0.3467 & 0.3089 & 0.2073 & 0.5000 & 2.1822 & 1.4837 & 0.3709 & 0.2615 & 2.4980 & 2.4980 & 3.8236 & 3.8236 & 3.8236 \\
\hline Depremsellik & 0.3371 & 2.4980 & 1.0000 & 1.0491 & 0.3150 & 2.8173 & 3.8883 & 3.8883 & 1.2247 & 0.3467 & 3.8236 & 3.8236 & 5.4106 & 5.4106 & 5.4106 \\
\hline Zemin Durumu & 0.3783 & 3.2377 & 0.9532 & 1.0000 & 0.2924 & 2.8173 & 3.8883 & 3.4641 & 1.0000 & 0.3150 & 3.8236 & 3.8236 & 5.2915 & 5.2915 & 5.2915 \\
\hline $\begin{array}{l}\text { Toplam İnşaat } \\
\text { Alanı }\end{array}$ & 1.2599 & 4.6857 & 3.1748 & 3.4200 & 1.0000 & 3.5954 & 4.5455 & 4.6857 & 3.2250 & 1.8171 & 4.8076 & 4.2831 & 6.0000 & 6.0000 & 6.0000 \\
\hline $\begin{array}{l}\text { Parselin Ada } \\
\text { İçindeki Konumu }\end{array}$ & 0.2537 & 2.0000 & 0.3550 & 0.3550 & 0.2791 & 1.0000 & 2.0801 & 1.4837 & 0.4454 & 0.2330 & 3.5328 & 3.5328 & 4.7301 & 4.7301 & 4.7301 \\
\hline Manzara & 0.2335 & 0.4575 & 0.2580 & 0.2580 & 0.2193 & 0.4799 & 1.0000 & 0.4673 & 0.2178 & 0.1877 & 1.7818 & 1.7818 & 3.0262 & 3.0262 & 3.0262 \\
\hline Bak1 & 0.2473 & 0.6740 & 0.2580 & 0.2896 & 0.2127 & 0.6740 & 2.1398 & 1.0000 & 0.3023 & 0.2615 & 2.1822 & 2.1822 & 3.5495 & 3.5495 & 3.5495 \\
\hline Eğim & 0.3709 & 2.6960 & 0.8151 & 1.0000 & 0.3101 & 2.2449 & 4.5919 & 3.3019 & 1.0000 & 0.3467 & 3.8236 & 3.8236 & 4.9328 & 4.9328 & 4.9328 \\
\hline $\begin{array}{l}\text { İmar Durumunda } \\
\text { Ada Kullanımı }\end{array}$ & 0.5503 & 3.8236 & 2.8845 & 3.1748 & 0.5494 & 4.2919 & 5.3454 & 3.8236 & 2.8845 & 1.0000 & 3.8467 & 3.7063 & 4.8203 & 4.8203 & 4.8203 \\
\hline $\begin{array}{l}\text { Merkeze Olan } \\
\text { Uzaklık }\end{array}$ & 0.2426 & 0.3996 & 0.2615 & 0.2615 & 0.2073 & 0.2840 & 0.5612 & 0.4575 & 0.2615 & 0.2608 & 1.0000 & 0.7418 & 1.9064 & 1.9064 & 1.9064 \\
\hline $\begin{array}{l}\text { Ana Caddeye } \\
\text { Olan Uzaklık }\end{array}$ & 0.2268 & 0.3996 & 0.2615 & 0.2615 & 0.2327 & 0.2840 & 0.5612 & 0.4575 & 0.2615 & 0.2707 & 1.3480 & 1.0000 & 1.8171 & 1.8171 & 1.8171 \\
\hline $\begin{array}{l}\text { Eğitim Alanına } \\
\text { Olan Uzaklık }\end{array}$ & 0.2003 & 0.2615 & 0.1860 & 0.1902 & 0.1664 & 0.2128 & 0.3305 & 0.2817 & 0.2020 & 0.2088 & 0.5246 & 0.5503 & 1.0000 & 1.5874 & 1.6984 \\
\hline $\begin{array}{l}\text { Yeşil Alana } \\
\text { Uzakl1k }\end{array}$ & 0.2003 & 0.2615 & 0.1860 & 0.1902 & 0.1664 & 0.2128 & 0.3305 & 0.2817 & 0.2020 & 0.2088 & 0.5246 & 0.5503 & 0.6300 & 1.0000 & 1.2599 \\
\hline $\begin{array}{l}\text { Sağlık Alanına } \\
\text { Olan Uzaklık }\end{array}$ & 0.2003 & 0.2615 & 0.1860 & 0.1902 & 0.1664 & 0.2128 & 0.3305 & 0.2817 & 0.2020 & 0.2088 & 0.5246 & 0.4486 & 0.5888 & 0.7937 & 1.0000 \\
\hline
\end{tabular}


15 anketten, 6 anketin tutarlı olduğu tespit edilmiştir. 6 ankette yer alan karşılaştırma matrislerinin geometrik ortalaması alınarak karşılaştırma matrisleri oluşturulmuştur. Matrisin her elemanı, sütunların toplamına bölünerek normalize edilmiş matris hesaplanmıştır (Tablo 2).

Tablo 2: Normalize edilmiş matris

\begin{tabular}{|c|c|c|c|c|c|c|c|c|c|c|c|c|c|c|c|}
\hline & 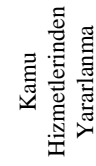 & 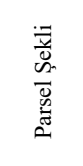 & 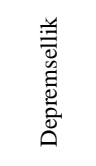 & 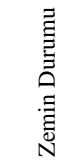 & 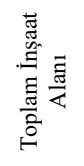 & 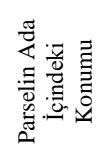 & 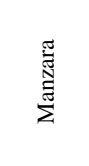 & $\overline{\bar{\omega}}$ & 澏 & 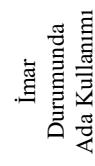 & 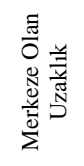 & 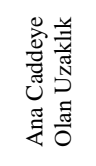 & 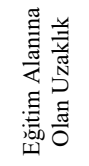 & 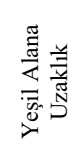 & 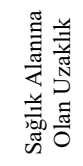 \\
\hline $\begin{array}{c}\text { Kamu } \\
\text { Hizmetlerinden } \\
\text { Yararlanma }\end{array}$ & 0.1670 & 0.1334 & 0.2582 & 0.1809 & 0.1551 & 0.1672 & 0.1191 & 0.1375 & 0.1860 & 0.2346 & 0.1077 & 0.1183 & 0.0956 & 0.0936 & 0.0926 \\
\hline Parsel Şekli & 0.0479 & 0.0382 & 0.0231 & 0.0212 & 0.0405 & 0.0212 & 0.0605 & 0.0505 & 0.0256 & 0.0338 & 0.0655 & 0.0673 & 0.0728 & 0.0712 & 0.0704 \\
\hline Depremsellik & 0.0563 & 0.0955 & 0.0667 & 0.0719 & 0.0615 & 0.1195 & 0.1078 & 0.1322 & 0.0845 & 0.0448 & 0.1002 & 0.1029 & 0.1030 & 0.1007 & 0.0997 \\
\hline Zemin Durumu & 0.0632 & 0.1238 & 0.0635 & 0.0686 & 0.0571 & 0.1195 & 0.1078 & 0.1178 & 0.0690 & 0.0407 & 0.1002 & 0.1029 & 0.1007 & 0.0985 & 0.0975 \\
\hline $\begin{array}{l}\text { Toplam İnşaat } \\
\text { Alanı }\end{array}$ & 0.2104 & 0.1792 & 0.2117 & 0.2344 & 0.1954 & 0.1525 & 0.1260 & 0.1594 & 0.2225 & 0.2346 & 0.1260 & 0.1153 & 0.1142 & 0.1117 & 0.1105 \\
\hline $\begin{array}{c}\text { Parselin Ada } \\
\text { İçindeki Konumu }\end{array}$ & 0.0424 & 0.0765 & 0.0237 & 0.0243 & 0.0545 & 0.0424 & 0.0577 & 0.0505 & 0.0307 & 0.0301 & 0.0926 & 0.0951 & 0.0900 & 0.0881 & 0.0871 \\
\hline Manzara & 0.0390 & 0.0175 & 0.0172 & 0.0177 & 0.0428 & 0.0204 & 0.0277 & 0.0159 & 0.0150 & 0.0242 & 0.0467 & 0.0480 & 0.0576 & 0.0563 & 0.0557 \\
\hline Bak1 & 0.0413 & 0.0258 & 0.0172 & 0.0199 & 0.0416 & 0.0286 & 0.0593 & 0.0340 & 0.0209 & 0.0338 & 0.0572 & 0.0588 & 0.0675 & 0.0661 & 0.0654 \\
\hline Eğim & 0.0619 & 0.1031 & 0.0543 & 0.0686 & 0.0606 & 0.0952 & 0.1273 & 0.1123 & 0.0690 & 0.0448 & 0.1002 & 0.1029 & 0.0939 & 0.0918 & 0.0909 \\
\hline $\begin{array}{l}\text { İmar Durumunda } \\
\text { Ada Kullanımı }\end{array}$ & 0.0919 & 0.1463 & 0.1923 & 0.2176 & 0.1073 & 0.1821 & 0.1482 & 0.1300 & 0.1990 & 0.1291 & 0.1008 & 0.0998 & 0.0917 & 0.0897 & 0.0888 \\
\hline $\begin{array}{l}\text { Merkeze Olan } \\
\text { Uzaklık }\end{array}$ & 0.0405 & 0.0153 & 0.0174 & 0.0179 & 0.0405 & 0.0120 & 0.0156 & 0.0156 & 0.0180 & 0.0337 & 0.0262 & 0.0200 & 0.0363 & 0.0355 & 0.0351 \\
\hline $\begin{array}{l}\text { Ana Caddeye } \\
\text { Olan Uzaklık }\end{array}$ & 0.0379 & 0.0153 & 0.0174 & 0.0179 & 0.0455 & 0.0120 & 0.0156 & 0.0156 & 0.0180 & 0.0350 & 0.0353 & 0.0269 & 0.0346 & 0.0338 & 0.0335 \\
\hline $\begin{array}{l}\text { Eğitim Alanına } \\
\text { Olan Uzaklık }\end{array}$ & 0.0335 & 0.0100 & 0.0124 & 0.0130 & 0.0325 & 0.0090 & 0.0092 & 0.0096 & 0.0139 & 0.0270 & 0.0138 & 0.0148 & 0.0190 & 0.0296 & 0.0313 \\
\hline $\begin{array}{l}\text { Yessil Alana } \\
\text { Uzaklık }\end{array}$ & 0.0335 & 0.0100 & 0.0124 & 0.0130 & 0.0325 & 0.0090 & 0.0092 & 0.0096 & 0.0139 & 0.0270 & 0.0138 & 0.0148 & 0.0120 & 0.0186 & 0.0232 \\
\hline $\begin{array}{l}\text { Sağlık Alanına } \\
\text { Olan Uzaklık }\end{array}$ & 0.0335 & 0.0100 & 0.0124 & 0.0130 & 0.0325 & 0.0090 & 0.0092 & 0.0096 & 0.0139 & 0.0270 & 0.0138 & 0.0121 & 0.0112 & 0.0148 & 0.0184 \\
\hline
\end{tabular}

Her faktörün satır değerleri toplanarak öncelik vektörü hesaplanmıştır (Tablo 3).

Sonraki aşamada öncelik vektörünün her satırı, karşılaştırma matrisinde karşılık gelen satırdaki değerler ile çarpılarak 'Tüm Öncelikler Matrisi’ oluşturulmuştur. Tüm öncelikler matrisi, öncelikler vektörüne ayrı ayrı bölünerek oluşturulan matrisin ortalaması alınır. Bu sayede CI hesaplanmıştır.

CI'nın, rastgele değer indeksine oranıyla tutarlılık oranı hesaplanmıştır (Tablo 4). Anket çalışmasının tutarlılık oranı, 0.05 olarak hesaplanmıştır. AHS'ye göre tutarlılık oranının 0.10 'dan büyük olduğu durumda yeniden değerlendirme yapılması 
gerekmektedir. Hesaplanan tutarlılık oranı, sınır değerden küçük olduğu için anket çalışması tutarlı kabul edilmiştir. Sonuç olarak arsa değerine etki eden faktörlerin ağırlıklarının belirlenmesi aşaması sona ermiştir.

Tablo 3: Öncelik vektörü

\begin{tabular}{cc}
\hline Faktör & A ğırlık Oranı (\%) \\
\hline Kamu Hizmetlerinden Yararlanma & 15.00 \\
\hline Parsel Şekli & 4.70 \\
\hline Depremsellik & 9.00 \\
\hline Zemin Durumu & 8.90 \\
\hline Toplam İnşaat Alanı & 16.70 \\
\hline Parselin Ada İçindeki Konumu & 5.90 \\
\hline Manzara & 3.30 \\
\hline Bakı & 4.20 \\
\hline Eğim & 8.50 \\
\hline İmar Durumunda Ada Kullanımı & 13.40 \\
\hline Merkeze Olan Uzaklık & 2.50 \\
\hline Ana Caddeye Olan Uzaklık & 2.60 \\
\hline Eğitim Alanına Olan Uzaklık & 1.90 \\
\hline Yeşil Alana Uzaklık & 1.70 \\
\hline Sağlık Alanına Olan Uzaklık & 1.60 \\
\hline
\end{tabular}

Tablo 4: Rastgele değer indeksi tablosu

\begin{tabular}{cc}
\hline Karar Alternatif Sayısı & Rastgele Dĕ̌er İndeksi \\
\hline 1 & 0.00 \\
\hline 2 & 0.00 \\
\hline 3 & 0.58 \\
\hline 4 & 0.90 \\
\hline 5 & 1.12 \\
\hline 6 & 1.24 \\
\hline 7 & 1.32 \\
\hline 8 & 1.41 \\
\hline 9 & 1.45 \\
\hline 10 & 1.49 \\
\hline 11 & 1.51 \\
\hline 12 & 1.48 \\
\hline 13 & 1.56 \\
\hline 14 & 1.57 \\
\hline 15 & 1.59 \\
\hline
\end{tabular}

Anket çalışması sonucunda belirlenen faktörlerin ağırlıkları; \%16.7 toplam inşaat alanı, \%15.0 kamu hizmetlerinden yararlanma, \%13.4 imar durumunda ada kullanımı, \%9.0 depremsellik, \%8.9 zemin durumu, \%8.5 eğim, \%5.9 parselin ada içindeki konumu, \%4.7 parsel şekli, \%4.2 bakı, \%3.3 manzara, \%2.6 ana caddeye olan uzaklık, \%2.5 merkeze olan uzaklık, \%1.9 eğitim alanına uzaklık, \%1.7 yeşil alana uzaklık ve \%1.6 sağlık alanına uzaklık şeklindedir. Arsa değerine etki eden faktörlerin oransal dağılımı Şekil 2'de verilmektedir.

\section{Uygulama}

\section{1 Çalışma Alanı}

Çalışma, Çanakkale ili, Merkez ilçesi, Esenler Mahallesi sınırları dahilinde gerçekleştirilmiştir. Esenler Mahallesi, 26² $24^{\prime}$ $26^{\circ} 26^{\prime}$ doğu meridyenleri ile 40 $9^{\prime}-40^{\circ} 10^{\prime}$ kuzey paralelleri arasında konumlanmıştır. Esenler Mahallesi, Merkez ilçenin gelişmekte olan, planlı ve tercih edilen bir bölgesidir. Çalışma alanı, Merkez ilçenin topoğrafik açıdan eğimi az olan 
bölgesidir (Şekil 3). Maden Tetkik ve Arama Genel Müdürlüğü bilgilerine göre Esenler Mahallesi’nde heyelan riski bulunmamaktadır. Türkiye İstatistik Kurumu verilerine göre, Esenler Mahallesi’nin nüfusu 2007 y1lında 15629 iken 2018 yılında 28 394'tür. Verilere göre Esenler Mahallesi’nin nüfusu 2013 yılından sonra sürekli artış göstermiştir.
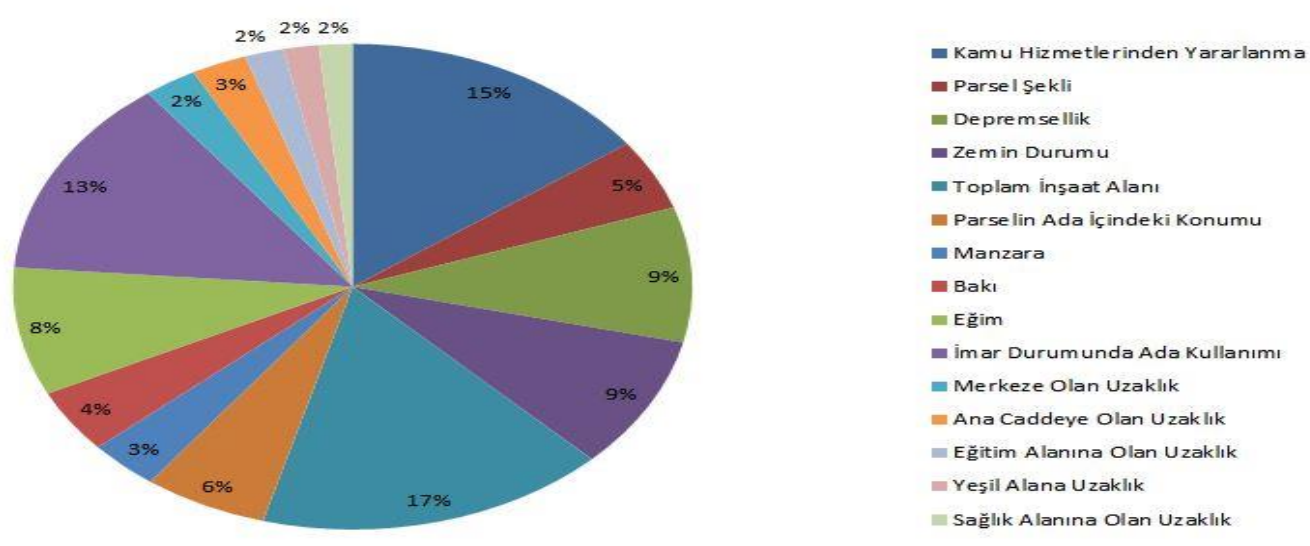

Şekil 2: Arsa değerine etki eden faktörler

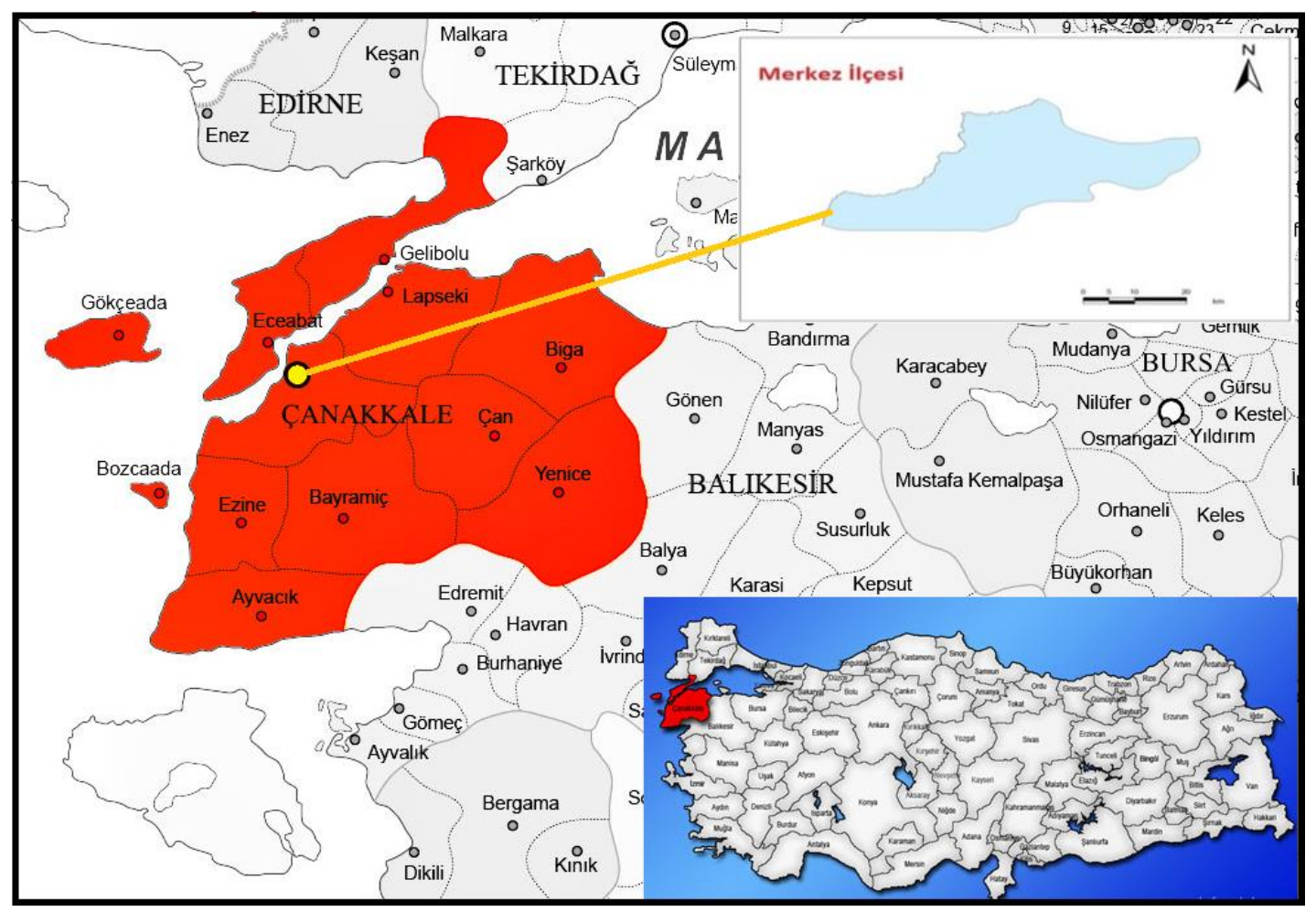

Şekil 3: Çalışma alanı

1915 Çanakkale Köprüsü’nün proje aşaması ile başlayan ve nitekim inşaatına başlanması ile devam eden süreçte Çanakkale ili taşınmaz değerleme alanında giderek önem kazanmıştır. Bölgeyle ilgili değer analizlerine ihtiyaç artmıştır. Bu ihtiyaçtan yola çıkılarak Çanakkale ilinin en hızlı gelişim gösteren bölgesi seçilerek değer haritası oluşturulması amaçlanmıştır (Şekil 4). Ayrıca Karacaören Köyü’nün belirli bir kısmının 1/1000 ölçekli uygulama imar planına dahil edilmesiyle birlikte bölge değer kazanmıştır. Bölgede yer alan caddelerin ticari faaliyet kazanması ile birlikte bölge gelişim göstermiştir. Bölgede yapılaşma koşullarının değişmesi ile konut alanında on kata kadar yapı yapılabilmesi ile yapısız arsalar değer kazanmıştır. Çanakkale ilini kapsayan konut projelerinin bu bölgede artış gösterdiği tespit edilmiştir. Özellikle Ahmet Piriştina Caddesi’ne yakın bir konumda 2017 yılından itibaren 15 adet sitenin inşaatına başlanmıştır. Ancak, inşaat sektöründe yaşanan durgunluk 
ile birlikte bölgenin kazandığı ivme yavaşlamıştır. 2018-2019 yıllarında konut projeleri tamamlanmıştır. Karacaören Caddesi’ne yakın konumda bulunan bölgede toplamda 5 adet nitelikli site ise proje aşamasındadır.

\subsection{Araştırma Bulguları}

Çalışma alanı olarak belirlenen Esenler Mahallesi'nde yer alan arsaların değer haritası oluşturulması işleminde ilk olarak bölgede yer alan yapısız, arsa vasıflı parseller belirlenmiştir. Öncelikli olarak Google Earth programı kullanılarak yapısız parseller belirlenmiştir. Tapu ve Kadastro Genel Müdürlüğü (TKGM) Parsel Sorgulama Uygulaması'nda belirlenen alanların, ada/parsel bilgilerine ulaşılmıştır. Sahada belirlenen parsellerin yerinde tespit işlemi yapılarak parsellerin güncel durumları belirlenmiştir. Sonuç olarak bölgede 87 adet yapısız parsel tespit edilmiştir.

NetCad 5.1 GIS programında bölgenin kadastral altlı̆̆ı oluşturulmuştur. 2019 yılına ait TKGM Parsel Sorgulama Uygulaması'nda parsellere ait 'Geo Json' verileri indirilerek NetCad 5.1 GIS programında yer alan makro uygulaması ile kadastral verilerde eksik olan parseller düzenlenmiştir. Bölgeyle ilgili yeşil alanlar, eğitim alanları, parsellerin şekli, depremsellik, zemin durumu gibi faktörlerin konumsal ve öznitelik verileri toplanmıştır. ArcGIS 10.5 yazılımında mesafe analizi işlemleri gerçekleştirilerek eğitim, sağlık, merkez, yeşil alan ve ana caddelere olan mesafe faktörleri ile ilgili veriler elde edilmiştir.

Belirlenen yapısız parsellerin öznitelik tablosu oluşturma işlemi Excel programında gerçekleştirilmiştir. Çanakkale Belediyesi Kent Rehberi’nden yararlanarak parsellerin 1/1000 ölçekli uygulama imar planı kapsamında lejantları ve yapılaşma koşulları verilerine ulaşılmıştır. Toplam inşaat alanı ve imar durumunda ada kullanımı faktörleri uygulama imar planına göre öznitelik tablosuna eklenmiştir (Şekil 5). Depremsellik faktöründe Afet ve Acil Durum Yönetimi Başkanlığ tarafından hazırlanan Türkiye Deprem Tehlike Haritaları İnteraktif WEB Uygulaması'nda yer alan PGA45 verisi referans alınmıştır. Zemin durumunda, bölgede bulunan zemin sınıfları, heyelan risk alanları ve sıvılaşma durumları göz önünde bulundurulmuştur. Esenler Mahallesi’nde mevcut durumda bulunan kamu hizmetleri tespit edilmiştir. Tespit edilen kamu hizmetleri doğalgaz, kanalizasyon, elektrik, yol ve sudur. Belirlenen parsellerin hepsi, kamu hizmetlerinin tamamindan yararlanmaktadır. Kamu hizmetlerinden yararlanma faktöründe öznitelik tablosuna eş değer veri girişi yapılmıştır. Parsel şekli faktöründe, parsellerin kırık köşe sayıları öznitelik tablosunda veri olarak tanımlanmıştır. Parsellerin konumlu olduğu ada içerisinde köşe veya ara parsel olup olmadığı tespit edilmiştir. Esenler Mahallesi’nde, denize yakın konumda bulunan parsellerde bulunan çok katlı apartmanların üst katlarında kısmi deniz manzarası bulunmaktadır. Bölgede belirlenen yapısız parsellerin deniz manzarası bulunmamaktadır. Manzara durumu faktörü göz önünde bulundurulduğunda öznitelik tablosuna eş değer veri girişi yapılmıştır. Öznitelik tablosu belirtilen faktörler göz önünde bulundurularak oluşturulmuştur. NetCad 5.1 GIS ortamında düzenlenen projede yer alan parseller; yapılı parseller, yapısız parseller ve kamu alanı olarak sınıflandırılmıştır. ArcGIS 10.5 programında oluşturulan öznitelik tablosu ile konumsal veri eşleştirilmiştir.

İmar durumunda ada kullanımı, parsellerin 1/1000 ölçekli uygulama planına göre yer aldıkları lejanta göre sınıflandırılmıştır. Kamu alanlarına ' 0 ' puan değeri, konut alanlarına '50' puan değeri ve ticaret alanlarına '100' puan değeri verilerek yeniden sınıflandırma işlemi gerçekleştirilmiştir. Depremsellik faktörü için ise Afet ve Acil Durum Yönetimi Başkanlığı tarafından oluşturulan Türkiye Deprem Tehlike Haritası ve İnteraktif Web Uygulaması'na göre parsellere ait yer ivmeleri sorgulanmıştır. PGA45 değerleri 0.305-0.309 değerleri arasında değişiklik göstermektedir. Belirlenen aralık 2. derece olarak sınıflandırılmaktadır. Bu sebeple parsellere ait depremsellik faktörü eşit şekilde puanlandırılmıştır.

Zemin durumu, çalışma alanının jeolojik durumu, zemin sınıfı, sıvılaşma durumu ve heyelan riski alt başlığında incelenmişstir. Bölgeye ait sıvılaşma tehlikesi ve heyelan riski bulunmamaktadır (Çavuş, 2014). Esenler Mahallesi, bölgeye ait jeoloji haritasına göre bölgenin tamamı homojen şekilde Çarmakdere Üyesi pekleşmiş alt kesim (Tçç1) ile Çarmakdere Üyesi 
pekleşmemiş üst kesimden (Tçç2) oluşmaktadır (Şekil 6). Çanakkale şehir yerleşimi dahilinde risk alanları analiz çalışmasında Çanakkale ili, Merkez ilçesinde 4 ayrı risk bölgesi tanımlanmıştır. Çalışma alanı, zemin durumu göz önünde bulundurulduğunda en az riskli bölgede yer almaktadır (Bekler, 2015). Zemin durumu faktörü de eşit şekilde puanlandırılmıştır.

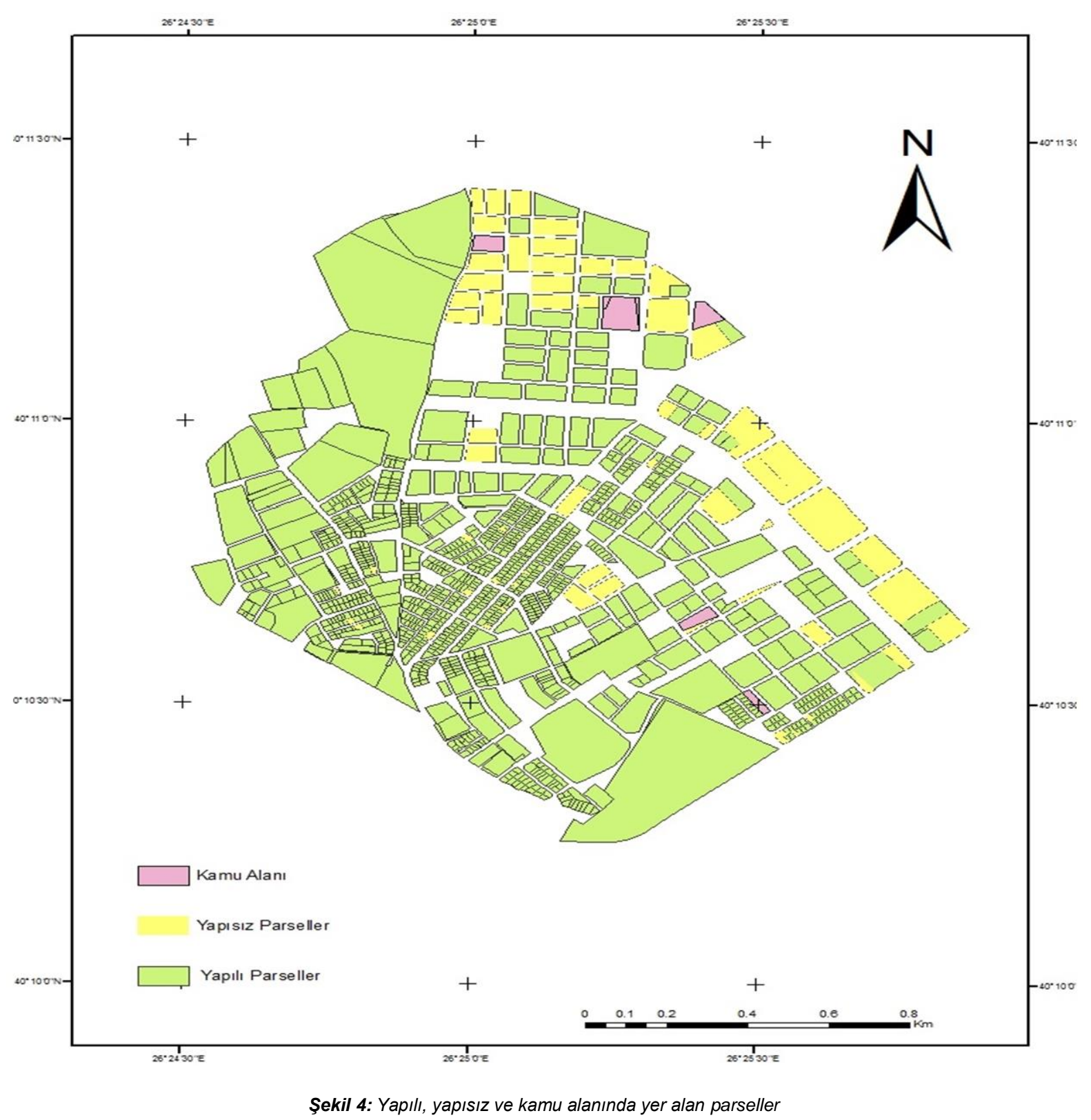

Eğim faktörü için çalışma alanına ait sayısal yükseklik modeli kullanılarak ArcGIS 10.5 programında eğim haritası oluşturulmuştur. Eğim durumları, 0-40 ile sınıflandırılmıştır. Yeniden sınıflandırma işlemi yapılarak 4 ayrı sınıf oluşturulmuştur. Eğim oranları ile puan değerleri ters orantılı olacak şekilde puanlama işlemi gerçekleştirilmiştir.

Bakı faktörü için çalışma alanına ait sayısal yükseklik modeli kullanılarak ArcGIS 10.5 programında bakı haritası elde edilmiştir. Parseller; kuzey, kuzeydoğu-kuzeybatı, güney, güneybatı-güneydoğu ve doğu-batı yönleri olarak sınıflandırılmıştır. Güney yönüne en yüksek değer verilecek şekilde kuzey yönüne doğru puanlama işlemi gerçekleştirilmiştir. CBS yazılımında elde edilen sayısal yükseklik modeli, bakı ve eğim haritaları sırasıyla Şekil 7'de verilmektedir.

Parselin ada içerisindeki konumu değerlendirilirken köşe parsel ya da ara parsel olma durumlarına göre yeniden sınıflandırma işlemi gerçekleştirilmiştir. Köşe parseller için ' 100 ' değeri, ara parseller için ‘ 0 ’ değeri verilerek puanlama işlemi yapılmıştır. 


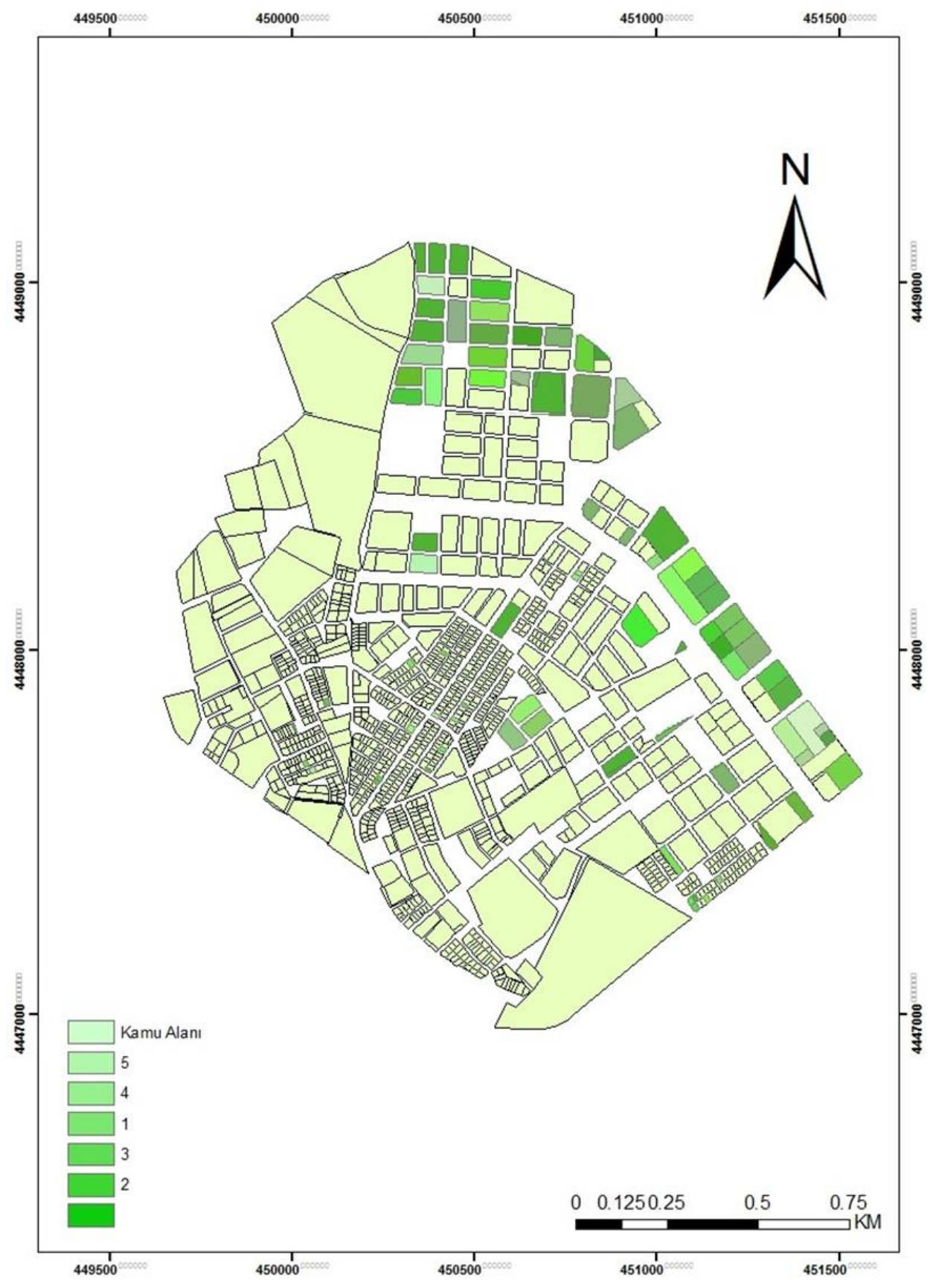

Şekil 5: Toplam inşaat alanı

Kamu hizmetlerinden yararlanma faktörü değerlendirilirken doğalgaz, elektrik, yol, kanalizasyon hizmetlerinden yararlanma durumları göz önünde bulundurulmuştur. Bölgede yer alan tüm parseller, kamu hizmetlerinin tamamından yararlanmaktadır. Parseller, eş değer şekilde sınıflandırılmıştır. Proje kapsamına yeni parsellerin eklenmesi durumunda puanlama hesabı Eşitlik 2 ile yapılabilir. Puanlandırma yararlanılan hizmet için ' 100 ' puan, yararlanılamayan hizmet için '0' puan şeklinde yapılmıştır (Yomralıoğlu, 1997). Eşitlikte geçen $\mathrm{Vu}_{\text {Kamu Hiz. }}$ değeri, mevcut kamu hizmetlerinin değere etkisini göstermektedir.

$\mathrm{Vu}_{\text {Kamu Hiz. }}=[\mathrm{TP}] / \mathrm{KH}$

KH: Kamu Hizmetleri Sayısı, TP: Toplam Puan 

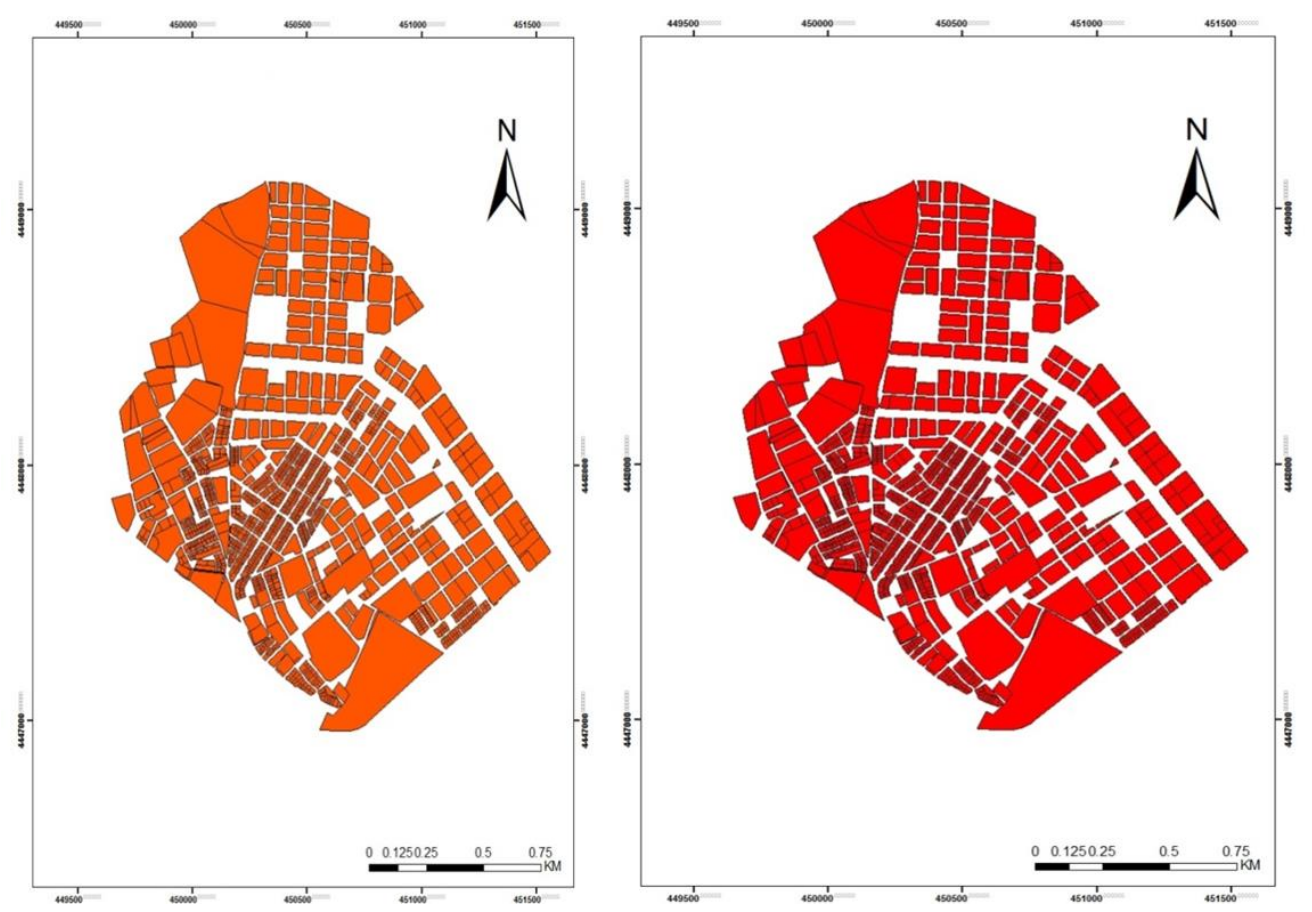

Şekil 6: Zemin durumu ve depremsellik haritaları

Esenler Mahallesi'nin batı cephesinde yer alan parsellerde deniz manzarası bulunmaktadır. Çalışma kapsamında bulunan parsellerin denize uzak konumda olması sebebiyle açık deniz manzarası bulunmamaktadır. Tüm parseller için eş değer puanlama işlemi gerçekleştirilmiştir.

Parsellerin köşe sayıları göz önünde bulundurularak 3, 4 ve 5 olarak öznitelik tablosuna veri girişi yapılmıştır. Tüm şartların aynı olması durumunda 4 köşesi bulunan parselin, inşaat ve proje maliyetlerinin daha az olması sebebiyle tercih edilebilirliği daha fazladır. Kamu hizmetlerinden yararlanma, parsel şekli, manzara durumu ve parselin ada içerisindeki konumuna ait haritalar Şekil 8'de verilmektedir.
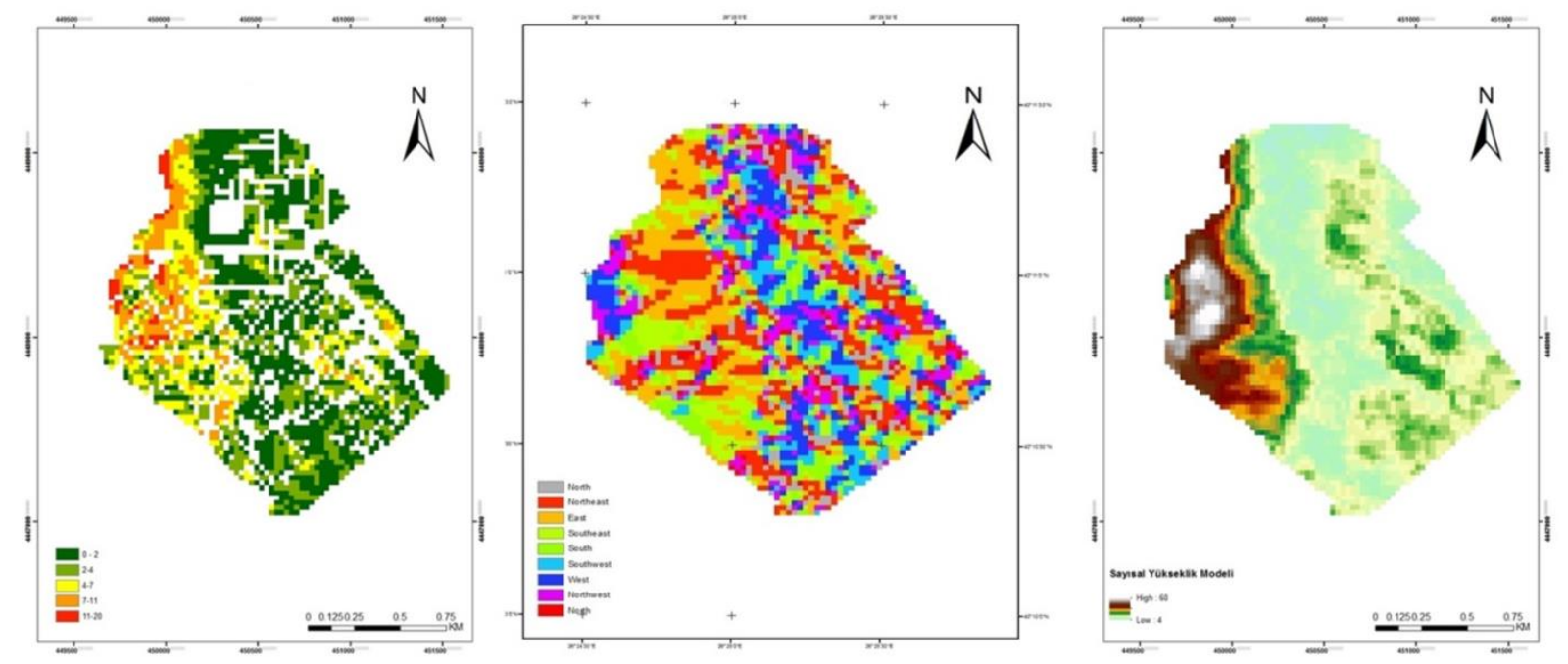

Şekil 7: Sayısal yükseklik modeli, bakı ve eğim haritaları 

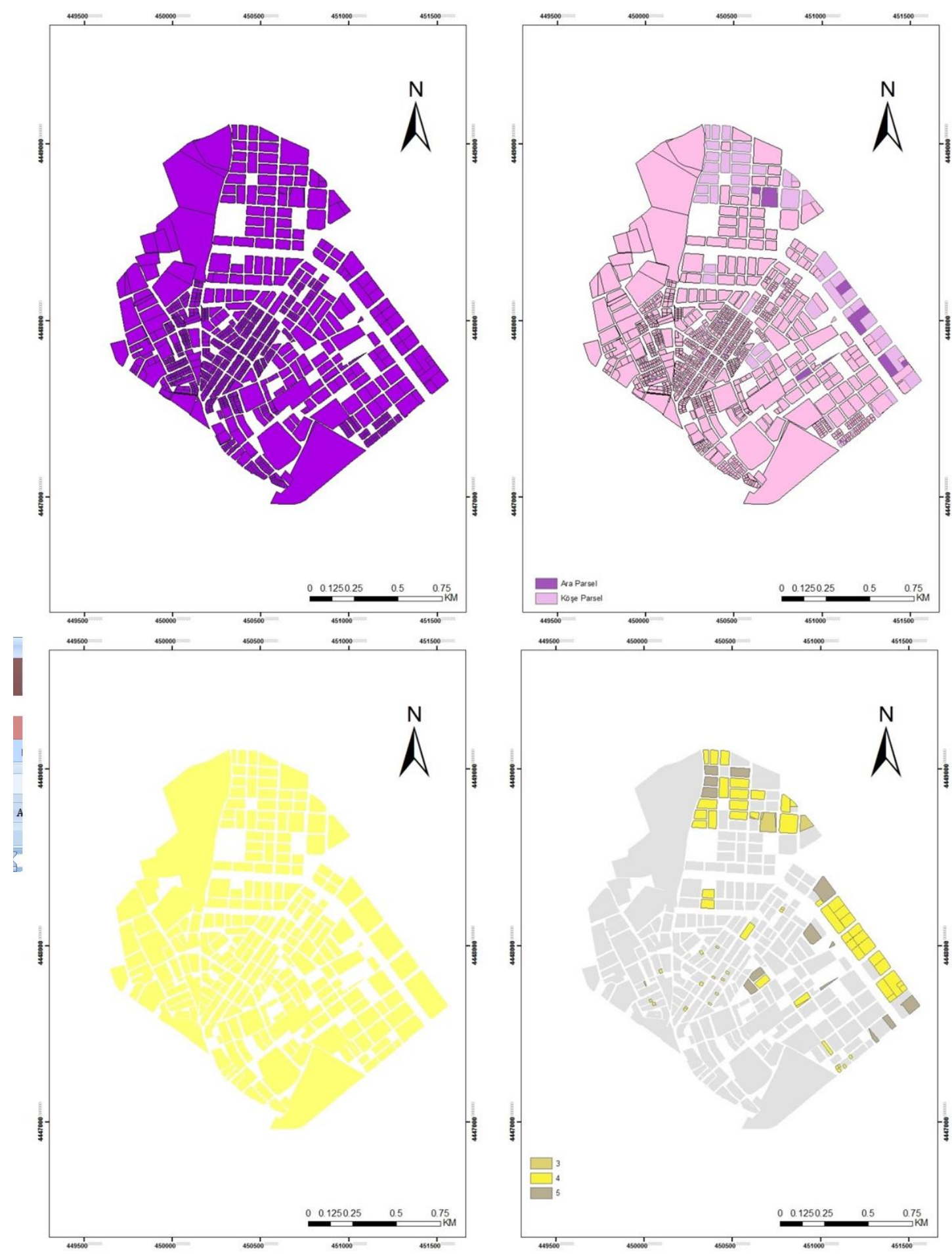

Şekil 8: Kamu hizmetlerinden yararlanma, parsel şekli, manzara durumu ve parselin ada içerisindeki konumuna ait haritalar

Ana caddeye uzaklık faktöründe bölgede yer alan caddelere olan uzaklıklar 0-500 metre aralı̆̆ referans alınarak mekânsal analiz işlemi gerçekleştirilmiştir. Söz konusu parametreler için elde edilen uzaklık haritaları Şekil 9'da verilmektedir. Çanakkale İskelesi merkez olarak kabul edilmiştir. Merkeze olan uzaklık ile ters orantılı olacak şekilde puanlama işlemi gerçekleştirilerek parseller 5 sınıfa ayrılmıştır. Yine ayrıca eğitim, sağlık ve yeşil alanların da parametre olarak kullanılarak elde edildiği haritalar Şekil 10'da verilmektedir. 

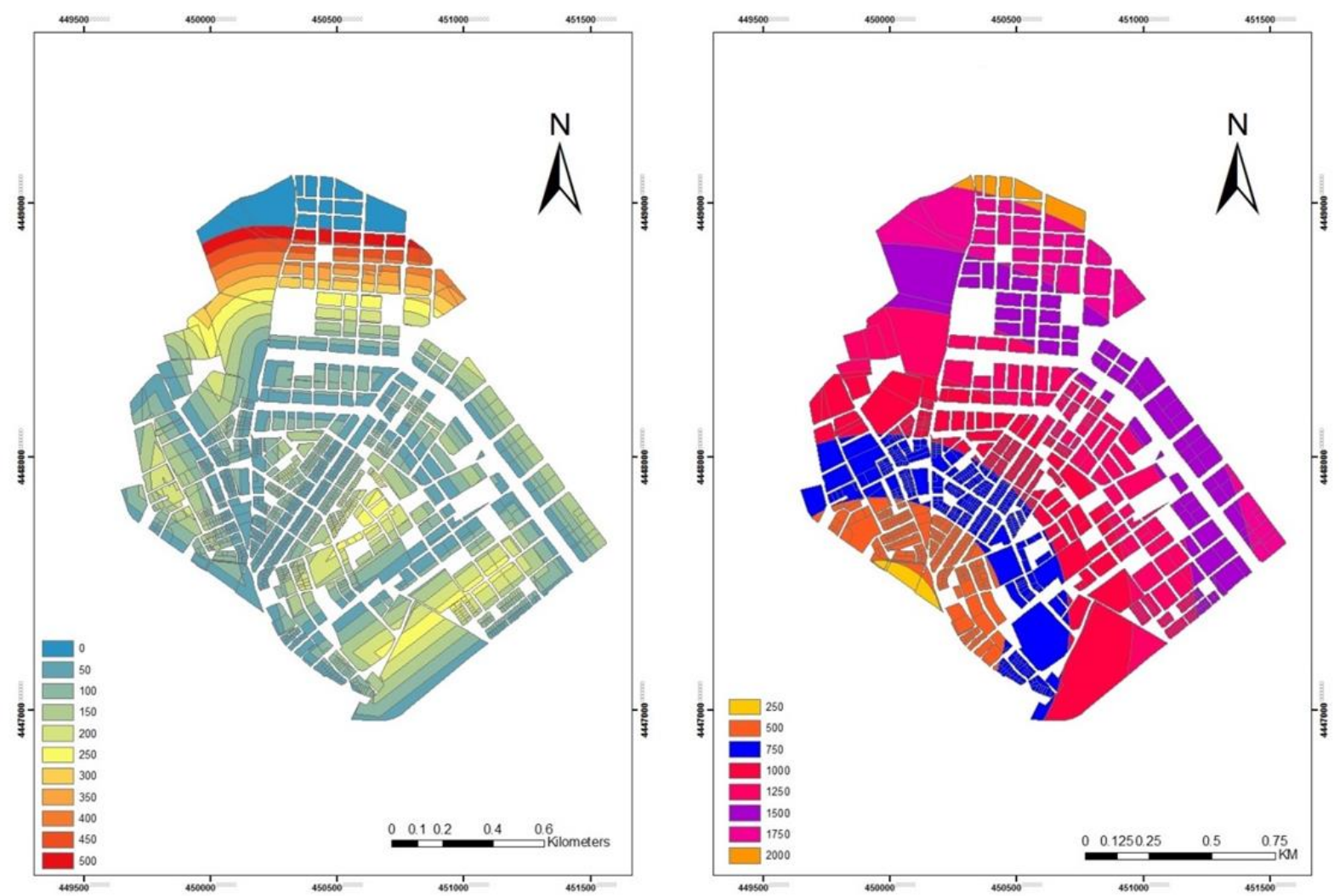

Şekil 9: Ana caddeye ve merkeze uzaklık haritaları
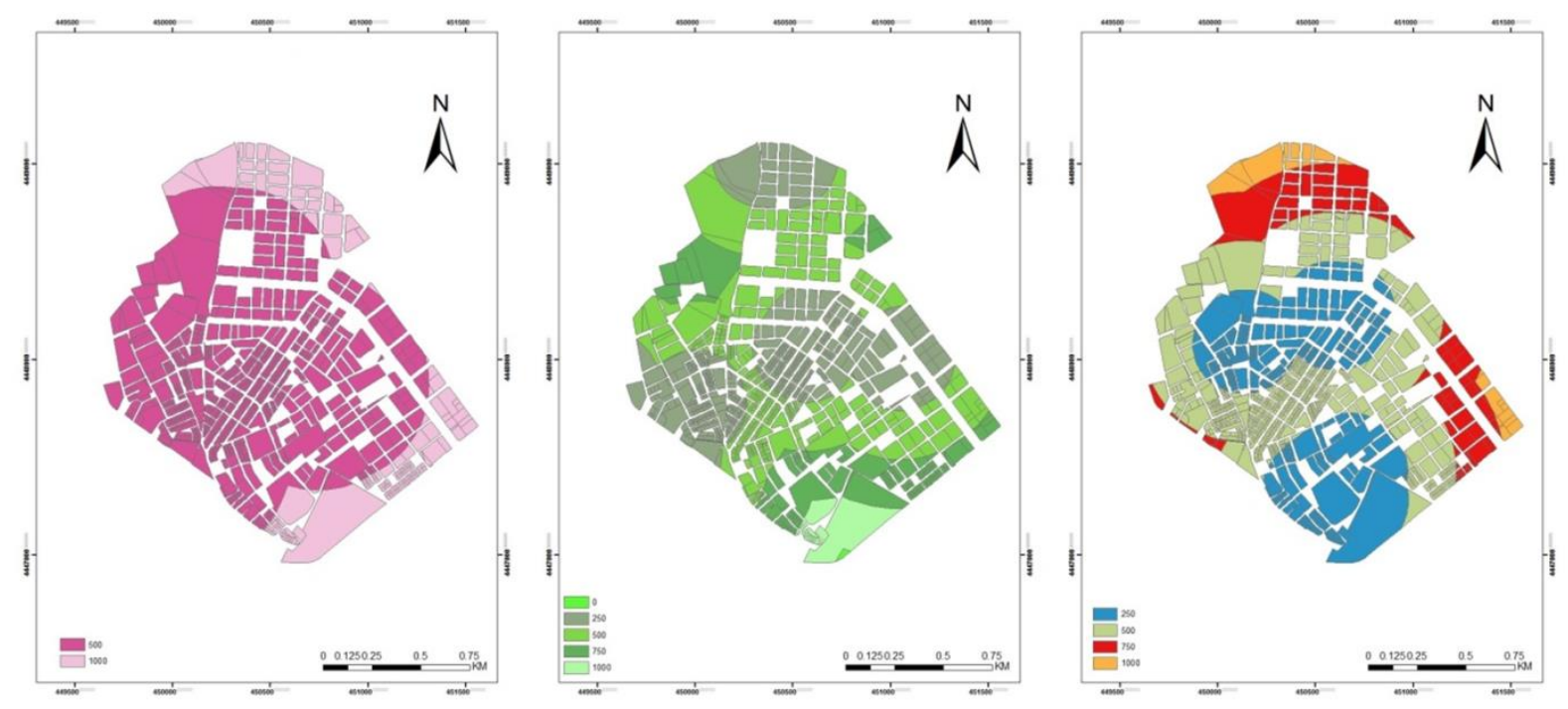

Şekil 10: Eğitim, sağlık ve yeşil alanlara olan uzaklık haritaları

Son olarak arsa değerine etki eden faktörlerin ağıllıkları göz önünde bulundurularak, tüm faktörlere ait haritalar ile ağırlıklı toplam aracı kullanılarak işlem gerçekleştirilmiştir. Arsa değerine etki eden faktörlerin ağırlıkları ve puanlama yöntemi ile parsele atanan puanlar göz önünde bulundurularak parselin değerine ulaşılmıştır. Elde edilen sonuç raster verisi, alan verisine dönüştürülmüştür. Sonrasında benzer özelliklere ait veriler bir araya getirilmiştir. Sonuç olarak bölgedeki yapısız parsellere ait değer haritası üretilmiştir. Parseller sonuç puanlarına göre 10 sınıfa ayrılmıştır. Yeniden sınıflandırma işlemi 10. sınıf en yüksek puanlı parsel olacak şekilde yapılmıştır. Belirtildiği gibi bu noktaya kadar çalışılan tüm parametrelerin ele alınarak çalışma alanında yer alan yapısız parsellere ait değer haritası ArcGIS 10.5 programında elde edilmiştir ve 10 farklı sınıfta Şekil 11'de verilmiştir. 


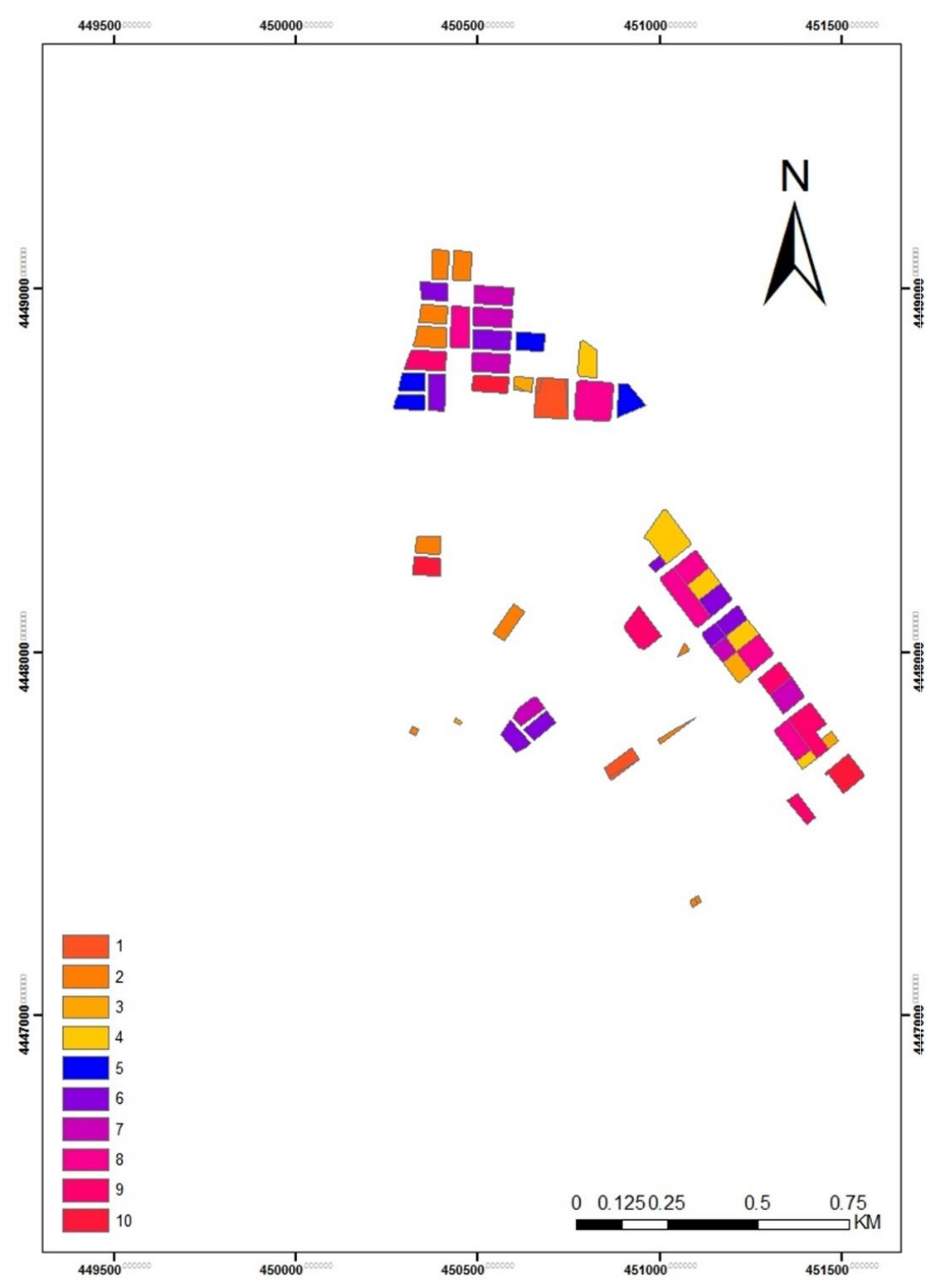

Şekil 11: Çalışma alanında yer alan yapısız parsellere ait değer haritalası

\section{Sonuç ve Öneriler}

Taşınmaz değerleme; bankacılık alanında finansman ve kredilendirme işlemleri, intikal davaları, vergilendirme ve sigortacılık işlemleri, kamulaştırma işlemleri, yatırım amaçlı işlemler gibi birçok alanda kullanılmaktadır. Belirtilen bu alanlarda kullanılan taşınmaz değerlemede en önemli amaç taşınmazın gerçek değerine ulaşabilmektir. Bu sebeple taşınmaz değerleme için bir sistem oluşturulması önem arz etmektedir.

Ülkemizde taşınmaz değerleme alanında taşınmazın değerine etki eden faktörlerle ilgili belirli bir standart oluşturulamamıştır. $\mathrm{Bu}$ sebeple taşınmazın değeri; değerleme uzmanlarına, değerleme şirketlerine ve banka standartlarına göre değişiklik göstermektedir.

Çalışma kapsamında çalışma alanı olarak seçilen Esenler Mahallesi’nde yer alan 87 adet arsayı kapsayan değer haritasının üretilmesi amaçlanmıştır. İlk aşama olarak arsa vasıflı taşınmazların değerini etkileyen faktörler belirlenmiştir. Belirlenen faktörlerin ağırlıklarının hesaplanması için AHS'ye göre anket formu oluşturulmuş ve bu form gayrimenkul değerleme uzmanları tarafindan cevaplanmıştır. 
Anket çalışması sonucunda belirlenen faktörlerin ağırlıkları; \%16.7 toplam inşaat alanı, \%15.0 kamu hizmetlerinden yararlanma, \%13.4 imar durumunda ada kullanımı, \%9.0 depremsellik, \%8.9 zemin durumu, \%8.5 eğim, \%5.9 parselin ada içindeki konumu, \%4.7 parsel şekli, \%4.2 bakı, \%3.3 manzara, \%2.6 ana caddeye olan uzaklık, \%2.5 merkeze olan uzaklık, \%1.9 eğitim alanına uzaklık, \%1.7 yeşil alana uzaklık ve \%1.6 sağlık alanına olan uzaklık şeklinde bulunmuştur. Bu faktörler haritalanmış ve ağırlık oranları dikkate alınarak Çanakkale ili, Merkez ilçesi, Esenler Mahallesi’nde yer alan yapısız parsellerin değer haritası üretilmiştir. Taşınmaz değerlemenin CBS ile ortak bir şekilde kullanılması objektif ve spekülatif olmayan gerçek değere daha hızlı ve daha güvenilir bir şekilde ulaşılmasını sağlamaktadır. Taşınmazların değerine etki eden faktörler ve faktör ağırlıklarının standartlaşması değerleme uzmanlarının objektif bir şekilde değerleme yapmasını sağlar.

Ülke genelinde CBS ile birlikte değer haritaları üretilerek taşınmaz değerleme sisteminin oluşturulması önem arz etmektedir. Taşınmaz değerleme sistemi ile birlikte veri tabanı oluşturulabilecektir. Oluşturulan veri tabanı ile geçmiş yıllara ait sorgulamalar yapılabilecektir. Bölgelere ait gelişimler analiz edilebilecektir. Taşınmaz değerleme çalışmalarında zaman ve emek kaybının önüne geçilebilecektir. Güncellenebilir bir taşınmaz değerleme sistemi ile birlikte bölgelere ait değişiklikler belirlenerek, değer artışına veya azalmasına neden olabilecek yerel faktörler göz önünde bulundurulabilecektir. Örneğin imalatı sürmekte olan 1915 Çanakkale Köprüsü Çanakkale'nin birçok bölgesinde taşınmaz değer artışına neden olan yerel bir faktör olarak gösterilebilir. Taşınmaz değerleme sistemi ile birlikte alım-satım yoğunluğunun yıllara dönük analizi gerçekleştirilebilecek ve yatırım amaçlı işlemlerde yapılacak olan değerlendirmede kolaylık sağlanabilecektir.

CBS tabanlı taşınmaz değerleme sistemi ile birlikte tüm resmî kurumlara ait verilerin bir araya getirilmesi ve kolay ulaşılabilmesi sağlanabilecektir. Güncel olarak taşınmazların satış değerleri sisteme eklenebilecek ve veri tabanı oluşturulabilecektir. Sistem ile birlikte gayrimenkul değerleme uzmanları verilere daha kolay ulaşabilecektir. Kullanılan değerleme yöntemine göre sonuçlar farklılık göstermekle birlikte daha hızlı ve daha güvenilir bir şekilde değer takdiri yapılabilir. Ayrıca değer haritaları ile birlikte mekânsal analizler gerçekleştirilebilecektir.

\section{Teşekkür}

Makale değerlendirme sürecinde çalışmanın bilimsel yönden geliştirilmesine çok değerli, faydalı öneri ve yorumlarıyla katkı sağlayan üç hakeme ve ayrıca yardımları ve yapıcı yorumları için derginin sorumlu editörüne teşekkür ederiz.

\section{Kaynaklar}

Akgün, A.A., Alkay, E., Kerimoğlu, E., Koramaz, T.K., Kundak, S., Okumuş, G. \& Özçevik, Ö. (2014). Şehir Planlamada Analiz ve Değerlendirme Teknikleri (s. 132-147). Literatür Yayıncılık.

Alonso, J. A., \& Lamata, M. T. (2006). Consistency in the analytic hierarchy process: a new approach. International journal of uncertainty, fuzziness and knowledge-based systems, 14(04), 445-459.

Bahar, M.E. (2007). Taşınmaz Değerlemesinde CBS'nin Kullanım Olanakları (Yüksek Lisans Tezi). İstanbul Teknik Üniversitesi Fen Bilimleri Enstitüsü, İstanbul, Türkiye.

Bekler, T. (2015). Alüvyon zemin tepkisinin jeofizik ve geoteknik yöntemlerle incelenmesi ve yerleşime uygunluk: Çanakkale şehri örneği. Türkiye Deprem Mühendisliği ve Sismoloji Konferansı, 14-16.

Ciritci, D., \& Türk, T. (2019). Alternatif katı atık depolama alanlarının analitik hiyerarşi süreci ve coğrafi bilgi sistemleri ile otomatik olarak belirlenmesi: Sivas ili örneği. Jeodezi ve Jeoinformasyon Dergisi, 6(1), 61-74.

Çakır, P., \& Sesli, F.A. (2013). Arsa vasıflı taşınmazların değerine etki eden faktörlerin ve bu faktörlerin önem sıralarının belirlenmesi. Harita Teknolojileri Elektronik Dergisi, 5(3), 1-16.

Çavuş, C. Z. (2014). Çanakkale Boğazı Doğusunda Arazi Kullanımı Uygunluğunun Yerleşme İçin Değerlendirilmesi (Doktora Tezi). 
Çanakkale Onsekiz Mart Üniversitesi Fen Bilimleri Enstitüsü, Çanakkale, Türkiye.

Derinpınar M.A. (2014). Bulanık Mantık ile Coğrafi Bilgi Teknolojileri Kullanarak Taşınmaz Değerlemesi: Sarıyer-İstanbul Örneği (Yüksek Lisans Tezi). İstanbul Teknik Üniversitesi Fen Bilimleri Enstitüsü, İstanbul, Türkiye.

Deveci, E., \& Yılmaz, İ. (2009). Coğrafi Bilgi Sistemleri Yardımıyla Taşınmaz Mal Değerlemesi: Afyonkarahisar İl Merkezi Örneği. Harita Teknolojileri Elektronik Dergisi, 1(1), 33-47.

Döner, S. (2010). CBS Destekli Taşınmaz Mal Değer Haritalarının Oluşturulması (Yüksek Lisans Tezi). İstanbul Teknik Üniversitesi Fen Bilimleri Enstitüsü, İstanbul, Türkiye.

Esogbue, A. O., Theologidu, M., \& Guo, K. (1992). On the application of fuzzy sets theory to the optimal flood control problem arising in water resources systems. Fuzzy Sets and Systems, 48(2), 155-172.

Görener, A. (2014). Depolama Faaliyetleri İçin Lojistik Servis Sağlayıcı Seçiminde Önemli Değerlendirme Kriterlerinin Belirlenmesi. Uluslararası Yönetim İktisat ve İşletme Dergisi, 10(22), 173-191.

Lai, S. (1995). Preference-based Interpretation of AHP. International Journal of Management Science, 23(4): 453-462.

Leung, P., Muraoka, J., Nakamoto, S. T., \& Pooley, S. (1998). Evaluating fisheries management options in Hawaii using analytic hierarchy process (AHP). Fisheries Research, 36(2-3), 171-183.

Mete, M. (2019). Coğrafi Bilgi Sistemleri ile İstanbul İli Nominal Taşınmaz Değer Haritasının Oluşturulması (Yüksek Lisans Tezi). İstanbul Teknik Üniversitesi Fen Bilimleri Enstitüsü, İstanbul, Türkiye.

Nişancı, R. (2005). Coğrafi Bilgi Sistemleri ile Nominal Değerleme Yöntemine Dayalı Piksel Tabanlı Kentsel Taşınmaz Değer Haritalarının Üretilmesi (Yüksek Lisans Tezi). Karadeniz Teknik Üniversitesi Fen Bilimleri Enstitüsü, Trabzon, Türkiye.

Özfidan, F. (2008). Taşınmaz Değerlemesi Bilgi Sistemi Tasarımı ve Uygulaması: Yenişehir Örneği (Yüksek Lisans Tezi). Zonguldak Karaelmas Üniversitesi Fen Bilimleri Enstitüsü, Zonguldak, Türkiye.

Saaty, T. (1980). The Analytic Hierarchy Process: Planning, Priority Setting. Resource Allocation. New York: McGraw-Hill.

Stylianidis, E., Roustanis, T., \& Karanikolas, N. (2009). A Geographical Information System for real estate (GEOVAL). In Location Based Services and Tele Cartography II (s. 317-329). Springer, Berlin, Heidelberg.

Timor, M. (2011). Analitik Hiyerarşi Prosesi (s. 301). İstanbul.

Timur, S. (2009). Coğrafi Bilgi Sistemleri Destekli Taşınmaz Değer Haritalarının Oluşturulması: İstanbul İli, Şişli İlçesi Örneği (Yüksek Lisans Tezi). İstanbul Teknik Üniversitesi Fen Bilimleri Enstitüsü, İstanbul, Türkiye.

Torun, M.K. (2009). Taşınmaz Değer Haritalarının Coğrafi Bilgi Sistemleri ile Üretilmesi (Yüksek Lisans Tezi). İstanbul Teknik Üniversite, İstanbul, Türkiye.

Turan, G. (2014). Çok Kriterli Karar Verme Yöntemleri. Bursa.

Tsai, W. H., Leu, J. D., Liu, J. Y., Lin, S. J., \& Shaw, M. J. (2010). A MCDM approach for sourcing strategy mix decision in IT projects. Expert Systems with Applications, 37(5), 3870-3886.

Ünlü, S. (2010). Coğrafi Bilgi Sistemi Yardımı ile Taşınmaz Değer Haritalarının Oluşturulması ve Eskişehir Örneği (Yüksek Lisans Tezi). Selçuk Üniversitesi Fen Bilimleri Enstitüsü, Konya, Türkiye.

Yacim, J. A., \& Boshoff, D. G. B. (2018). Impact of artificial neural networks training algorithms on accurate prediction of property values. Journal of Real Estate Research, 40(3), 375-418.

Yener, S. (2017). Gayrimenkul Değerlemesinde Değer Haritalarının Oluşturulması ve Haritalar Yardımıyla Gayrimenkul Değerinin Tespit Edilmesi (Yüksek Lisans Tezi).Marmara Üniversitesi, İstanbul, Türkiye.

Yılmaz, A. (2011). Çok Ölçütlü KararDestek Sistemleri ile Taşınmaz Değerleme ve Oran Çalışması (Yüksek Lisans Tezi). Yıldız Teknik Üniversitesi, Fen Bilimleri Enstitüsü, İstanbul, Türkiye.

Yomralığlu, T. (1997). Eşdeğer İlkesine Dayalı Arsa ve Arazi Düzenlemesi Modeli. JEFOD Kentsel Alan Düzenlemelerinde İmar Planı Uygulama Teknikleri, 139-152.

Yomralığlu, T., Nişancı, R., \& Uzun, B. (2007). Raster Tabanlı Nominal Değerleme Yöntemine Dayalı Arsa-Arazi Düzenlemesi Uygulaması, TMMOB Harita ve Kadastro Mühendisleri Odası 11. Türkiye Harita Bilimsel ve Teknik Kurultayl.

Yomralığlu, T. (2015). Coğrafi Bilgi Sistemleri (6. Baskı, s. 479). İstanbul.

Zeng, T. Q., \& Zhou, Q. (2001). Optimal spatial decision making using GIS: a prototype of a real estate geographical information system (REGIS). International Journal of Geographical Information Science, 15(4), 307-321. 